\title{
Therapeutic vaccines in non-small cell lung cancer
}

\author{
This article was published in the following Dove Press journal: \\ ImmunoTargets and Therapy \\ 18 September 2013 \\ Number of times this article has been viewed
}

Francisco Socola'

Naomi Scherfenberg ${ }^{2}$

Luis E Raez ${ }^{3}$

'Division of Hematology/Oncology, Sylvester Comprehensive Cancer

Center, University of Miami Leonard

M Miller School of Medicine, Miami,

Florida, USA; ${ }^{2}$ University of Miami

Leonard M Miller School of Medicine,

Miami, Florida, USA; ${ }^{3}$ Thoracic

Oncology Program, Memorial

Cancer Institute, Memorial Health

Care System, Pembroke Pines,

Florida, USA
Correspondence: Francisco Socola Division of Hematology/Oncology, Sylvester Comprehensive Cancer Center, University of Miami Leonard M Miller

School of Medicine, I475 NW I2th

Avenue, D8-4 Miami, FL 33I36, USA

Tel + I 3052436554

Fax + I 3052433289

Email fsocola@med.miami.edu
Abstract: Non-small cell lung cancer (NSCLC) unfortunately carries a very poor prognosis. Patients usually do not become symptomatic, and therefore do not seek treatment, until the cancer is advanced and it is too late to employ curative treatment options. New therapeutic options are urgently needed for NSCLC, because even current targeted therapies cure very few patients. Active immunotherapy is an option that is gaining more attention. A delicate and complex interplay exists between the tumor and the immune system. Solid tumors utilize a variety of mechanisms to evade immune detection. However, if the immune system can be stimulated to recognize the tumor as foreign, tumor cells can be specifically eliminated with little systemic toxicity. A number of vaccines designed to boost immunity against NSCLC are currently undergoing investigation in phase III clinical trials. Belagenpumatucel-L, an allogeneic cell vaccine that decreases transforming growth factor (TGF- $\beta$ ) in the tumor microenvironment, releases the immune suppression caused by the tumor and it has shown efficacy in a wide array of patients with advanced NSCLC. Melanoma-associated antigen A3 (MAGE-A3), an antigen-based vaccine, has shown promising results in MAGE-A3 ${ }^{+}$NSCLC patients who have undergone complete surgical resection. L-BLP25 and TG4010 are both antigenic vaccines that target the Mucin-1 protein (MUC-1), a proto-oncogene that is commonly mutated in solid tumors. CIMAVax is a recombinant human epidermal growth factor (EGF) vaccine that induces anti-EGF antibody production and prevents EGF from binding to its receptor. These vaccines may significantly improve survival and quality of life for patients with an otherwise dismal NSCLC prognosis. This review is intended to give an overview of the current data and the most promising studies of active immunotherapy for NSCLC.

Keywords: immunotherapy, non-small cell lung cancer, Belagenpumatucel-L, melanomaassociated antigen A3 (MAGE-A3), L-BLP25, TG4010, CIMAVax

\section{Introduction}

Lung cancer is the leading cause of cancer mortality in the US and worldwide, accounting for over one million deaths annually. Approximately $85 \%$ of newly diagnosed lung cancers are categorized as non-small cell lung cancers (NSCLC). ${ }^{1}$ NSCLC includes squamous cell carcinoma, adenocarcinoma, and large cell carcinoma. Unlike other common types of solid tumors, such as breast cancer and colon cancer, there are no screening modalities for early detection of lung cancer in the general population., ${ }^{2,3}$ As a result, many of these patients have locally advanced or metastatic disease by the time they become symptomatic and present for care. Patients with stage IIIb or IV NSCLC are deemed to have unresectable tumors and while they may benefit from palliative chemotherapy, radiation, or both, a cure is unlikely. Even if the NSCLC 
can be completely resected, the 5-year mortality is $40 \%$ in stage I disease, $66 \%$ in stage II disease, and $75 \%$ in stage IIIa loco-regional disease. Micrometastases are commonly left behind after surgical resection, resulting in eventual relapse. As such, a diagnosis of NSCLC carries a poor prognosis under all circumstances. ${ }^{4}$

Systemic chemotherapy for NSCLC has reached a plateau in effectiveness for several years and certainly biological therapy (approved antiangiogenic agents and tyrosine kinase inhibitors) has slightly improved survival; however, the mortality of NSCLC is very high and survival after development of metastatic disease is less than 2 years. Therefore, new approaches are required to improve current outcomes. $^{5}$

Active-specific immunotherapy is an area of oncology that is rapidly expanding and delivering promising results such as asymptomatic prostate cancer with the use of sipuleucel-T. ${ }^{6}$ In the field of lung cancer, there are multiple vaccines focused on creating specific antitumor activity in NSCLC (Table 1). ${ }^{7}$

Table I Therapeutic vaccines in NSCLC

\begin{tabular}{|c|c|c|c|}
\hline Target & Composition & Features & Indication \\
\hline Belagenpumatucel-I & $\begin{array}{l}\text { Allogeneic } \\
\text { tumor cells } \\
\text { from } 4 \\
\text { irradiated } \\
\text { NSCLC cell } \\
\text { lines }\end{array}$ & $\begin{array}{l}\text { Cell lines } \\
\text { transfected } \\
\text { with a TGF-2 } \\
\text { antisense }\end{array}$ & $\begin{array}{l}\text { Stage IIla/b } \\
\text { and IV after } \\
\text { chemoradiation } \\
\text { or platinum } \\
\text { based } \\
\text { chemotherapy }\end{array}$ \\
\hline MAGE-A3 & $\begin{array}{l}\text { Purified } \\
\text { MAGE-A3 } \\
\text { recombinant } \\
\text { protein }\end{array}$ & $\begin{array}{l}\text { Liposomal } \\
\text { formulation } \\
\text { containing the } \\
\text { ASI5 Adjuvant } \\
\text { System }\end{array}$ & $\begin{array}{l}\text { Stage Ib, II and } \\
\text { Illa after } \\
\text { surgical } \\
\text { resection } \\
\text { +/- adjuvant } \\
\text { chemotherapy }\end{array}$ \\
\hline L-BLP25 & $\begin{array}{l}\text { Tumor- } \\
\text { associated } \\
\text { MUC-I }\end{array}$ & $\begin{array}{l}\text { Liposomal } \\
\text { vaccine } \\
\text { containing } \\
\text { BLP25 } \\
\text { lipopeptide an } \\
\text { immunoadjuvant } \\
\text { and } 3 \text { lipids }\end{array}$ & $\begin{array}{l}\text { Stage Illb } \\
\text { unresectable } \\
\text { after } \\
\text { chemoradiation } \\
\text { or } \\
\text { chemotherapy }\end{array}$ \\
\hline TG40I0 & $\begin{array}{l}\text { Tumor- } \\
\text { associated } \\
\text { MUC-I }\end{array}$ & $\begin{array}{l}\text { Recombinant } \\
\text { viral vector } \\
\text { expressing both } \\
\text { MUC-I and } \\
\text { interleukin-2 }\end{array}$ & $\begin{array}{l}\text { Stage IV with } \\
\text { chemotherapy } \\
\text { or after it. }\end{array}$ \\
\hline EGF & $\begin{array}{l}\text { Human } \\
\text { recombinant } \\
\text { EGF }\end{array}$ & $\begin{array}{l}\text { Recombinant } \\
\text { EGF conjugated } \\
\text { to an } \\
\text { immunoadjuvant }\end{array}$ & $\begin{array}{l}\text { Stage IIlb/IV } \\
\text { after first line } \\
\text { chemtherapy }\end{array}$ \\
\hline
\end{tabular}

Note: Data from. ${ }^{7}$

Abbreviations: EGF, epidermal growth factor; NSCLC, non-small cell lung cancer; MAGE, melanoma-associated antigen; TGF, transforming growth factor; MUC-I, Mucin-I.

\section{The immune system in NSCLC}

The immune system plays an important role in the interaction between cancer and its host. Scientists have long understood that tumors can be recognized by a patient's immune system. Rare reports dating back to the 1800 s have documented spontaneous tumor regression after infectious events. ${ }^{8}$ Such regressions, however, are usually seen in only very immunogenic tumors, such as renal cell carcinoma and melanoma. ${ }^{9,10}$ NSCLC is a notoriously non-immunogenic cancer, or a cancer in which we have been unable to trigger an appropriate immune response for multiple reasons and this characteristic has limited the development of immune therapies for NSCLC. ${ }^{11}$ If, however, the immune system can be stimulated to recognize the tumor as an antigen, it can be utilized to specifically attack the tumor. This strategy allows the patient to avoid toxicities, like myelosuppression, neutropenic fever, mucositis, hair loss, and GI disturbance, which arise from indiscriminately destroying all dividing cells with systemic chemotherapy. Therapeutic vaccines have been developed for the treatment of other types of cancers. For example, Sipuleucel-T is a monoclonal antibody vaccine in phase III clinical trials that modulates $\mathrm{T}$ cell activity in patients with metastatic melanoma and castrate-resistant prostate cancer. ${ }^{6,12}$ There is evidence to suggest that a similar approach could be very beneficial to the survival and quality of life of NSCLC patients. $^{7}$

Malignant cells may express or be induced to express antigens that identify themselves to the immune system as foreign invaders that must be removed. Dendritic cells (DCs) and macrophages process and present these antigens in the complex of major histocompatibility (MHC) class I and class II molecules. This antigen presentation results in the activation of immune effector cells, namely cytotoxic T lymphocytes (CTLs). These CTLs then recognize the antigens on tumor cells and induce apoptosis via granzyme and perforin production. In NSCLC, many of the infiltrating $\mathrm{T}$ lymphocytes are actually immunosuppressive regulatory $T$ cells (CD25+), which secrete transforming growth factor $\beta$ (TGF- $\beta$ ) and dampen the immune response to the tumor. ${ }^{13}$ In the presence of TGF- $\beta$, the formerly potent CTLs will now tolerate the tumor-associated antigens, rather than causing apoptosis. Tumor cells can also favor tolerant DCs that drive the differentiation of $\mathrm{T}$ cells towards the immunosuppressive regulatory $\mathrm{T}$ cells, rather than the cytotoxic $\mathrm{T}$ cells. Thus, there are many targets that can be utilized to induce immunogenicity of NSCLC. ${ }^{13}$

Active immunotherapy has been proposed as a novel method to palliate metastatic and non-operable NSCLC 
patients and as an adjuvant therapy to surgical resection. A therapeutic vaccine is composed of one or more tumor antigens, and sometimes with an adjuvant that the immune system recognizes as foreign. Such a vaccine induces a powerful and enduring immune response to the specific tumor antigen(s). Via the immune mechanism described above, the tumor antigens are taken up by DCs and CTLs are subsequently activated for tumor destruction. ${ }^{14}$

Vaccines can either be immune system modulators directed to allow de novo generation of antitumor activity or agents that elicit specific antitumor activity, known as therapeutic cancer vaccines. ${ }^{15}$ Therapeutic cancer vaccines are classified in either whole-cell vaccines or vaccines that target specific antigens. These vaccines have been developed for all stages of NSCLC and have been studied in Phase II and are currently undergoing Phase III clinical trials (Tables 1 and 2). $.16,17$

A good example of a whole cell vaccine is Belagenpumatucel-L, developed from four different NSCLC cell lines, each with an antisense gene for TGF- $\beta 2$. There are different vaccines that target specific antigens in the cancer cell, including the melanoma-associated antigen A3 (MAGE-A3; only found in cancer cells) vaccine, while the L-BLP25 and TG4010 vaccines are antigen vaccines that target the Mucin-1 protein. Finally, the CIMAVax vaccine targets EGF and prevents it from binding with its receptor, effectively preventing tumor growth. Each of these vaccines has shown promising results in Phase II trials (Table 1) and offers many potential targets for the directed treatment and improved survival of NSCLC patients (Table 1$).^{5}$

\section{Early studies of immunotherapy for lung cancer}

Lung cancer immunotherapy before 1990 focused on nonspecific immune stimulants including Bacille Calmette-Guerin (BCG), thymosin, and Corynebacterium parvum. ${ }^{18}$ Small cell lung cancer (SCLC) was commonly investigated because it was feasible to treat patients with minimal residual disease following curative chemotherapy and radiation.

Two larger series of patients with lung cancer treated with BCG found improvements in survival compared to historical controls, as well as a survival benefit for intrapleural BCG injection for patients with pleural effusions. ${ }^{19,20}$ Patients with adenocarcinomas were reported to respond better than those with squamous cell carcinomas. ${ }^{21}$ Excitement about nonspecific agents was tempered, however, by a randomized study of BCG as adjuvant therapy for SCLC demonstrating no impact on overall survival. ${ }^{22}$ In addition, a study of preoperative intra-tumoral injection of BCG found no impact on disease-free or overall survival; ${ }^{23}$ however, both of these randomized trials were underpowered to detect small differences. The role of BCG in lung cancer immunotherapy is now primarily as an adjuvant immune stimulant with autologous tumor or antigen-specific vaccine strategies. ${ }^{24} \mathrm{~T}$ cell growth factor thymosin, another nonspecific immune stimulant, was found to have activity in combination with chemotherapy, especially among patients whose immune systems were not activated at the time therapy was initiated. ${ }^{25}$

Similarly, early studies using the bacterium C. parvum as a systemic antitumor agent for NSCLC demonstrated doserelated tumor responses, but no effect on overall survival. ${ }^{18}$

During the 1990s, nonspecific immunotherapy was attempted with interleukin (IL)-2 and other cytokines or inflammatory mediators. For example, Schiller et al ${ }^{26}$ reported a series of 15 patients with advanced lung cancer treated with IL-2 and tumor necrosis factor (TNF)- $\alpha$. Cardiopulmonary toxicity was common, and there were no significant tumor responses. Similarly, a combination of IL-2 and interferon (IFN)- $\alpha$ demonstrated no benefit. ${ }^{27} \mathrm{~A}$ combination of IL-2 and melatonin, on the other hand, demonstrated a clinical benefit ( $20 \%$ partial response, $50 \%$ stable disease) in a study of 20 patients. ${ }^{28}$

\section{Types of therapeutic vaccines in non-small cell lung cancer}

There are two types of vaccines in NSCLC: passive and active immunization. Passive immunization involves the administration of antibodies, as intramuscular immune globulin derived from pooled human serum or antitoxin derived from serum harvested from immunized animals (Table 3). Passive immunization offers short-term protection to people who have been or will be exposed to a specific pathogen and is typically used by immunocompromised patients who are unable to produce an effective immune response with active immunization.

Active immunization involves the administration of antigens that stimulate the host to produce a primary immune response (usually by inducing B cell proliferation, antibody response, and T cell sensitization; Table 4). If an individual is subsequently exposed to the pathogen against which the vaccine is directed, the exposure results in a secondary response that includes increased proliferation of $\mathrm{B}$ cells and formation of antibodies. The secondary response protects the individual from developing disease, ideally for life. 


\section{Passive immunizations for NSCLC}

Nowadays, there are multiple monoclonal antibodies to treat different types of cancer, such as rituximab for lymphoma and transtuzumab for breast cancer. So far, however, passive immunotherapy has not made an impact on lung cancer.

Trastuzumab (anti-human epidermal growth factor receptor [HER] 2 antibody) has been evaluated for patients with advanced NSCLC. In a Phase II study of 24 patients with HER-2 overexpressing tumors, only one patient had a partial clinical response to therapy. In another study, trastuzumab was tested in combination with chemotherapy for advanced NSCLC. None of the 13 HER2-positive patients in this cohort responded to targeted therapy. ${ }^{29}$

Another agent that has been developed recently is an antibody targeting the ganglioside fucosyl GM-1. In preclinical studies, this drug was shown to decrease formation of metastatic lung cancer via antibody-dependent cell-mediated cytotoxicity. Antigen-specific radioimmunotherapy has been attempted for SCLC by utilizing bispecific monoclonal antibodies. This was felt to be a promising treatment strategy because SCLC is highly radiosensitive. In one study, anticarcinoembryonic antigen (CEA) antibody was attached to a radionucleotide-binding antibody; 3 of 12 patients responded to this treatment. ${ }^{30}$

\section{Active immunizations for NSCLC}

There are different active vaccines for NSCLC, the two most important ones are whole cell vaccines and antigen specific vaccines.

\section{Whole cell vaccines \\ Belagenpumatucel-L}

Belagenpumatucel-L is an allogeneic whole cell vaccine that was created from four different NSCLC cell lines (one squamous cell carcinoma, one large cell carcinoma, and two adenocarcinoma) that were genetically modified to elaborate an antisense oligonucleotide to TGF- $\beta 2$. Because this vaccine was created from multiple cell lines, it has a wide array of antigens and is thus potentially beneficial in most NSCLC patients. TGF- $\beta$ suppresses the activity of natural killer cells, CTLs, and dendritic cells, effectively shutting down antitumor immune function. TGF- $\beta$ also has the capacity to convert immature $\mathrm{T}$ cells to immunosuppressive regulatory $\mathrm{T}$ cells by inducing the transcription factor Forkhead box P3 (FOXP3). Preclinical studies revealed that antisense inhibition of TGF- $\beta 2$ expression enhances effector cell-mediated tumor death. High TGF- $\beta 2$ levels are associated with poor prognosis in NSCLC. Fortunately, Belagenpumatucel-L causes the downregulation of TGF- $\beta 2$. By decreasing the amount of TGF- $\beta 2$ in the tumor microenvironment, immunity against the tumor is restored. ${ }^{31}$

In a Phase II trial by Nemunaitis et al, in 2006, 75 NSCLC patients with stage II-IV disease were randomized to receive intradermal injections with one of three different dosage levels of Belagenpumatucel-L $\left(1.25 \times 10^{7}, 2.5 \times 10^{7}\right.$, or $5 \times$ $10^{7}$ cells/injection) either every month or every 2 months, up to a maximum of 16 doses. Study participants were required to have an estimated tumor burden of $125 \mathrm{~mL}$ or less excluding bone and nodal disease, but there were no restrictions in regards to previous therapies. Most of these patients (61 of 75) had advanced disease that could not be surgically resected. Fifteen percent of the study participants with advanced diseased showed a partial response to the experimental treatment. The study revealed two important points about this vaccine. First, the patients who received one of the two higher dosage levels $\left(>2.5 \times 10^{7}\right.$ cells/injection) had a significantly improved overall survival rate of $47 \%$ relative to the overall survival rate of $18 \%$ for participants who received the low dosage level $\left(1.25 \times 10^{7}\right.$ cells/injection; $\left.P=0.0069\right)$. Second, a subgroup analysis performed on those patients that had a partial response along with antibody-mediated response showed a significant increase in the production of interferon- $\Upsilon$, IL-4, and IL-6 $(P=0.014)$. The overall survival rate of 32.5 months among responders constitutes a statistically significant increase in response compared to patients who did not respond; these control patients had an overall survival of 11.6 months $(P=0.011)$. Belagenpumatucel- $\mathrm{L}$ demonstrated minor toxicity with only one grade 3 adverse event. This was a single patient who developed edema at the injection site. Although another participant developed chronic myelogenous leukemia 5 months after the final cycle of treatment with Belagenpumatucel- $\mathrm{L}$, this event was reportedly unrelated to vaccine administration. ${ }^{32}$

Based on the promising results of the Phase II trial, the survival, tumor-free, overall, and progression-free (STOP) Phase III randomized placebo-controlled clinical trial was designed to assess whether Belagenpumatucel-L can prolong the overall survival of stage III and IV NSCLC patients by at least three months. ${ }^{6}$ Patients with stage IIIa/IIIb, or IV NSCLC will receive 18 monthly immunizations $(2.5 \times$ $10^{7}$ cells/injection) followed by two booster injections at 3 month intervals. Controls receive best supportive care and placebo injections. To qualify for enrollment, patients must have responded to chemotherapy or had stable disease following a platinum-based chemo regimen. The primary endpoint is overall survival with secondary endpoints of 
Table 2 Phase III clinical trials of therapeutic vaccines in NSCLC

\begin{tabular}{|c|c|c|c|c|c|c|c|}
\hline \multirow[t]{2}{*}{ Vaccine } & \multirow[t]{2}{*}{ Target } & \multirow[t]{2}{*}{ Study } & \multirow{2}{*}{$\begin{array}{l}\text { Estimated } \\
\text { total } \\
\text { Patients (n) }\end{array}$} & \multirow[t]{2}{*}{ Stage } & \multirow[t]{2}{*}{ Study design } & \multirow[t]{2}{*}{$\begin{array}{l}\text { Primary } \\
\text { endpoint }\end{array}$} & \multirow{2}{*}{$\begin{array}{l}\text { Estimated } \\
\text { completion } \\
\text { Date }\end{array}$} \\
\hline & & & & & & & \\
\hline Belagenpumatucel-L & TGF- $\beta 2$ & $\begin{array}{l}\text { STOP (Survival, tumor-free, } \\
\text { overall and progression-free) } \\
\text { Trial }^{33}\end{array}$ & 506 & $\begin{array}{l}\text { IIla, IIlb, } \\
\text { or IV }\end{array}$ & $\begin{array}{l}\text { Vaccine + BSC vs } \\
\text { placebo + BSC } \\
\text { after response to } \\
\text { chemotherapy }\end{array}$ & $\begin{array}{l}\text { Overall } \\
\text { survival }\end{array}$ & $\begin{array}{l}\text { October } \\
2012\end{array}$ \\
\hline MAGE A3 & $\begin{array}{l}\text { Melanoma- } \\
\text { associated } \\
\text { antigen A3 }\end{array}$ & $\begin{array}{l}\text { MAGRIT (MAGE-A3 as } \\
\text { adjuvant non-small cell lung } \\
\text { cancer immunotherapy) Trial }{ }^{36}\end{array}$ & 2,270 & $\begin{array}{l}\text { Ib, Il, or } \\
\text { Illa }\end{array}$ & $\begin{array}{l}\text { Resection + } \\
\text { chemotherapy + } \\
\text { vaccine vs } \\
\text { Resection + } \\
\text { vaccine in } \\
\text { MAGE-A3 + } \\
\text { patients }\end{array}$ & $\begin{array}{l}\text { Disease- } \\
\text { free } \\
\text { survival }\end{array}$ & $\begin{array}{l}\text { October } \\
2016\end{array}$ \\
\hline L-BLP25 & $\begin{array}{l}\text { Mucin-I } \\
\text { protein }\end{array}$ & $\begin{array}{l}\text { START (stimulating targeted } \\
\text { responses to NSCLC trial) }\end{array}$ & I,476 & Illb & $\begin{array}{l}\text { L-BLP25 + BSC or } \\
\text { BSC alone after } \\
\text { response to } \\
\text { chemotherapy }\end{array}$ & $\begin{array}{l}\text { Overall } \\
\text { survival }\end{array}$ & $\begin{array}{l}\text { September } \\
2014\end{array}$ \\
\hline TG40I0 & $\begin{array}{l}\text { Mucin-I } \\
\text { protein }\end{array}$ & $\begin{array}{l}\text { TIME (TG40 I } 0 \text { immunotherapy in } \\
\text { patients with stage IV non-small cell } \\
\text { lung cancer) Trial }{ }^{44}\end{array}$ & 1,000 & IV & $\begin{array}{l}\text { Chemotherapy + } \\
\text { TG40I0 vs } \\
\text { Chemotherapy + } \\
\text { placebo }\end{array}$ & $\begin{array}{l}\text { Overall } \\
\text { survival }\end{array}$ & $\begin{array}{l}\text { December } \\
2016\end{array}$ \\
\hline CIMAVax-EGF & EGF & $\begin{array}{l}\text { A Phase II/III trial to assess the safety, } \\
\text { immunogenicity and preliminary } \\
\text { efficacy of recombinant human } \\
\text { EGF-rP64K/montanide ISA } 5 \text { I vaccine } \\
\text { administered to patients with non- } \\
\text { small-cell lung cancer (NSCLC) } \\
\text { after receiving conventional first } \\
\text { line chemotherapy }\end{array}$ & 579 & $\begin{array}{l}\text { IIlb or } \\
\text { IV }\end{array}$ & $\begin{array}{l}\text { CIMAVax + BSC } \\
\text { or BSC alone after } \\
\text { responding to } \\
\text { chemotherapy }\end{array}$ & $\begin{array}{l}\text { Overall } \\
\text { survival }\end{array}$ & Complete \\
\hline
\end{tabular}

Abbreviations: BSC, best supportive care; Cl, confidence interval; EGF, epidermal growth factor; HR, hazard ratio; MAGE, melanoma-associated antigen; NSCLC, non-small cell lung cancer; TGF, transforming growth factor; vs, versus.

progression-free survival, quality of life, and time to progression. This trial had an estimated completion date of October 2012 and enrolled 506 patients. ${ }^{33}$

\section{Antigen specific vaccines MAGE-A3}

MAGE-A3, a melanoma-associated antigen, is a specific tumor antigen that is not found on normal cells. MAGE$\mathrm{A} 3$ is found only in the testis, but it is not presented as an antigen because of the lack of MHC class I molecules in this immune-privileged location. The MAGE-A3 protein is expressed in a variety of cancers, including $35 \%$ of NSCLC. MAGE-A3 expression is associated with

Table 3 Passive immunization

\begin{tabular}{ll}
\hline Advantage & Disadvantages \\
\hline Immediate immunity & Costly \\
Pharmacologic control & Temporary immunity \\
Rapid development time & Requires IV administration \\
High specific activity & Dose response uncertain \\
There are no memory antibodies & \\
\hline
\end{tabular}

Abbreviation: IV, intravenous. poor prognosis, and the rate of expression increases as the disease progresses $(30 \%$ in stage I NSCLC and $50 \%$ in stage II NSCLC). MAGE-A3 gene activation occurs early in lung carcinogenesis and this epitope has well-documented CTL immunogenicity. MAGE-A3 is found most frequently in squamous cell carcinoma amongst the NSCLCs. The MAGE-A3 vaccine is an antigen vaccine that consists of a full-length MAGE-A3 protein complexed to part of the Hemophilus influenzae protein $\mathrm{D}$, packaged with lipid adjuvants. It has been designed for use in the postoperative setting in patients with stage I, II, or IIIa cancer. In patients who have undergone surgical resection, the clinical usefulness of these vaccines is maximized because of the lower

Table 4 Active immunization

\begin{tabular}{ll}
\hline Advantage & Disadvantages \\
\hline Long protection & $\begin{array}{l}\text { Depend on host immune system } \\
\text { (not everyone may be protected) }\end{array}$ \\
Less costly & Protective response takes time \\
Less side effects & Long development time \\
Memory antibodies production & Dose response uncertain \\
\hline
\end{tabular}


postoperative tumor burden and the more direct access vaccine has to all tumor cells. ${ }^{34}$

In the Phase II trial by Vansteenkiste et al in 2007, 182 MAGE-A3+ patients with surgically resected stage $\mathrm{Ib}$ and II NSCLC received induction with five doses of either MAGE-A3 $300 \mu \mathrm{g}$ vaccine or placebo every 3 weeks and then maintenance therapy of eight doses or placebo every 3 months. Follow-up at 28 months revealed improved diseasefree interval (primary endpoint) in the treatment group with a hazard ratio of 0.74 (95\% confidence interval [CI] 0.44-1.2; $P=0.107)$. In study participants with stage $\mathrm{Ib} / \mathrm{II}$ resected NSCLC, treatment with the MAGE-A3 vaccine decreased the risk of recurrence by $25 \%$ (hazard ratio $[\mathrm{HR}]=0.75$; 95\% CI 0.46-1.23). Moreover, in those participants with documented MAGE-A3 expression, treatment decreased relative risk of recurrence by $43 \%(\mathrm{HR}=0.57 ; 95 \% \mathrm{CI}$ $0.25-1.34)$. Although these results did not reach statistical significance, a clear survival benefit was observed in this trial. After a median follow-up of 44 months, only $30.3 \%$ of the treatment group experienced relapse, compared to a rate of $41.7 \%$ in the control group. The vaccine was welltolerated with only mild flu-like symptoms and injection site reactions. ${ }^{35}$

Following the results of the Phase II trial, MAGE-A3 as adjuvant non-small cell lung cancer immunotherapy (MAGRIT), the largest Phase III lung cancer study in history, was designed and is ongoing. MAGRIT is a randomized, double-blinded, placebo-controlled study that evaluates the use of the MAGE-A3 vaccine as adjuvant therapy. Study participants have completely resected stage Ib, II, or IIIa NSCLC, and are MAGE-A3+ by polymerase chain reaction (PCR). The study also compares the efficacy of MAGE-A3 vaccine in participants who underwent resection and adjuvant chemotherapy with a control group who solely underwent resection prior to vaccination. Patients in the study are assigned in a 2:1 ratio to the treatment group versus the placebo group. Five doses are to be administered at 3-week intervals for induction and followed by maintenance therapy with vaccination every 12 weeks. The primary objective is disease-free survival in MAGE-A3 treatment after complete resection. Secondary objectives include efficacy in the overall population and efficacy in patients who did not receive adjuvant chemotherapy. A recent meta-analysis on 7,626 patients from 25 different randomized trials revealed a pronounced correlation between disease-free survival and overall survival. These results lend further credibility to the use of disease-free survival rates as a primary endpoint. ${ }^{3}$ The MAGRIT trial is ongoing, with a planned enrollment of 2,270 patients, and has an estimated completion date of October 2016. ${ }^{36}$

\section{Mucin-I targets: L-BLP25 and TG40I0}

Mucin-1 (MUC-1) is a transmembrane protein normally found on the apical surface of cells. In many malignancies, MUC-1 is found to be overexpressed and under-glycosylated or aberrantly glycosylated. This deranged glycosylation can unmask epitopes on the peptide core that may act as tumor-associated antigens. MUC-1 is an oncogene common to breast, lung, colon, pancreatic, and ovarian cancers that is believed to be involved in tumor cell migration and resistance to chemotherapy-related apoptosis. High serum MUC-1 levels are associated with poor survival, presumably due to immune suppression in the tumor microenvironment. MUC-1, abnormally expressed in almost half of all NSCLC, has been proven to inhibit physiologic $\mathrm{T}$ cell proliferation. This activity of MUC-1 decimates the host's antitumor immune response, which normally relies on CTL tumor cell killing. MUC-1 oncogene immune evasion by CTL inhibition is confirmed by the administration of IL-2, which circumvents this process and stimulates $\mathrm{T}$ cell proliferation. The glycosylation pattern on the abnormally expressed MUC-1 in NSCLC makes it an attractive target for immune therapy. ${ }^{37}$

L-BLP25 (Stimuvax) is a 20-amino acid peptide with low-dose cyclophosphamide in a liposomal vehicle. The cyclophosphamide is used to interfere with the number and function of $\mathrm{CD} 25$ regulatory $\mathrm{T}$ cells in the tumor microenvironment. The liposomal vehicle enhances tumorassociated antigen recognition. This synthetic vaccine targets the exposed core of MUC-1 when aberrantly glycosylated, which induces immune response against the tumor cell. Antigen-specific CTL proliferation and production of IFN- $\Upsilon$ occur in response to vaccine administration. ${ }^{38}$

A randomized Phase II trial was conducted by Butts et al in 2007 on 171 stage IIIb or IV NSCLC patients after response or stable disease to first-line chemotherapy. Participants were then randomized to receive either L-BLP25 with best supportive care or, alternatively, best supportive care alone. Patients undergoing the treatment regime received a single dose of cyclophosphamide $300 \mathrm{mg} / \mathrm{m}^{2}$ three days before administration of the vaccine, followed by eight doses of L-BLP25 vaccine $(1000 \mu \mathrm{g})$, given weekly. Maintenance vaccinations could be given to the study group every 6 weeks thereafter, at the discretion of the investigator, until the patient exhibited disease progression. The primary objective was median overall survival, which was 17.2 months in the treatment group versus 13.0 months in the control group (adjusted HR $=0.739 ; 95 \%$ 
CI $0.509-1.073 ; P=0.112$ ). Although this difference was not statistically significant, subgroup analysis performed in those patients with stage IIIb locoregional disease $(n=35)$ showed a more pronounced separation between the treatment and control groups. Stage IIIb NSCLC patients in the treatment group had a median overall survival of 30.6 months, compared to 13.3 months in the control group (adjusted HR $=0.524$; 95\% CI 0.261-1.052; $P=0.069) .{ }^{3}$ Common adverse events included mild flu-like symptoms, injection site reactions, and nausea due to cyclophosphamide administration. In patients who received ongoing maintenance therapy, adverse events decreased with time and no long-term safety issues were identified. ${ }^{39,40}$

Although Phase II trials with L-BLP25 did not produce statistically significant results, L-BLP25 did seem to benefit those receiving it. The benefits were particularly pronounced in patients with stage IIIb NSCLC. These results have prompted a large Phase III randomized placebo-controlled clinical trial called stimulating targeted responses to NSCLC trial (START). An estimated 1476 patients with unresectable stage III NSCLC and response or stable disease after chemotherapy will be randomized 2:1 to receive L-BLP25 with best supportive care or placebo with best supportive care. The primary endpoint will be overall survival, ${ }^{3}$ and the estimated study completion date is September 2014. ${ }^{41}$

The TG4010 DNA vaccine also targets the aberrant MUC-1 protein. Ankara virus, an attenuated vaccinia virus, is genetically modified to express MUC-1 and IL-2. The MUC-1 is the tumor antigen, but the immunogenicity of the vaccine is further enhanced by the function of IL-2 to facilitate growth and proliferation amongst the CTLs that will ultimately cause the apoptosis of tumor cells. ${ }^{42}$ A Phase II clinical trial compared TG4010 plus first-line chemotherapy to TG4010 alone in 65 patients with stage IIIb or IV NSCLC. Patients in the experimental group received TG4010 with cisplatin and vinorelbine. Patients in the control group received TG4010 monotherapy until progression of disease was demonstrated, at which point they were given the same regimen as patients in the experimental group. The median overall survival for group 1 (vaccine + chemotherapy) was 12.7 months versus 14.9 months for group 2 (vaccine until progression, then chemotherapy added). The 1-year survival rate was $60 \%$ in the experimental group versus $53 \%$ in the control group. TG4010 was well-tolerated with only mild flu-like symptoms and injection site reactions. ${ }^{42}$

A Phase IIb trial by Acres et $\mathrm{al}^{43}$ was conducted in 2009 in which 148 untreated MUC-1+ patients were randomized to receive cisplatin and gemcitabine, with or without TG4010.
In the experimental group, TG4010 was given every 3 weeks until progression of disease was detected. The primary endpoint was progression-free survival (PFS). This endpoint was observed in $44 \%$ of the experimental group versus $35 \%$ in the "chemotherapy only" control group $(P=0.13)$. Higher response rates, a secondary endpoint, were observed in the vaccinated group (43\% versus $27 \% ; P=0.03$ ). Subgroup analysis in patients with normal levels of activated natural killer cells showed increased response rate and overall survival in the vaccinated group (58\% versus $38 \%, P=0.04$; 18 months versus 11.3 months; $P=0.02) .{ }^{43}$ Based on these results, a Phase IIb/III randomized, double-blinded, placebocontrolled trial is now enrolling approximately 1,000 patients with stage IV NSCLC and normal levels of activated natural killer cells. In this study, TG4010 immunotherapy in patients with stage IV NSCLC (TIME), study participants will either receive chemotherapy with TG4010 or chemotherapy with a placebo until disease progression is observed. The primary endpoint is overall survival rate and the study is estimated to be complete in December $2016 .{ }^{44}$

\section{CIMAVax EGF vaccine}

Epidermal growth factor (EGF) and its cell receptor are overexpressed in many carcinomas, including NSCLC. EGF binds to its receptor on cells and provides signaling for cell growth and proliferation. The EGF receptor (EGFR) pathway inhibitors like monoclonal antibodies and tyrosine kinase inhibitors have shown great efficacy in clinical practice. The EGF vaccine CIMAVax was developed in Cuba with recombinant human EGF, P64K Neisseria meningitides carrier protein, and immunoadjuvant Montanide ISA 51. Administration of the vaccine causes production of anti-EGF antibody against EGF. This prevents EGF from binding to its receptor, inhibiting tumor growth..$^{45,46}$

Three pilot studies were initially conducted to optimize the formulation of the vaccine. Pooled data of the 83 patients with stage IIIb/IV NSCLC in these three studies revealed that $83 \%$ of vaccinated patients at least doubled their baseline anti-EGF antibody titers, referred to as seroconversion. Theoretically, higher antibody titers correspond with better response to treatment, so these studies sought to create a vaccine that induces the highest possible anti-EGF antibody titer. Results revealed that Montanide ISA 51 was an effective immunoadjuvant and that pre-treatment with cyclophosphamide enhances antibody titer response to the vaccination. The combined results of the three trials revealed that patients with seroconversion had an 11.1 month overall survival versus a 5.7 month overall survival in participants who did not 
seroconvert $(P=0.005)$. The data also revealed that patients who achieved antibody titers above the median (median maximal antibody titer 1:4,000) had a survival advantage over participants with titers below the median (12.2 months versus 8.1 months; $P=0.036$ ). During the course of these studies, researchers recognized that antibody titers waned relatively quickly without subsequent vaccination, but also that antibody titers could be easily recovered with the use of booster vaccines. ${ }^{47}$

A Phase II study by Neninger et $\mathrm{al}^{48}$ on CIMAVax in 2003, involved 80 participants with stage IIIb or IV NSCLC who had received first line chemotherapy prior to the study. Participants were randomized to receive either CIMAVax and best supportive care or to receive best supportive care alone. Those in the experimental group received priming with low dose cyclophosphamide, followed by $50 \mu \mathrm{g}$ doses of EGF vaccine administered on days 1, 7, 14, 28, and then monthly. Serum EGF levels were measured in both groups and were found to be lower in the vaccine group, confirming that CIMAVax induces production of the anti-EGF antibodies that lower serum EGF concentration. Median survival was improved in the experimental group (6.5 months versus 5.3 months; $P=0.098$ ). Although these results were not significant, a subgroup analysis amongst patients under 60 years old did reveal a significant survival advantage in the experimental group (11.6 months versus 5.3 months; $P=0.0124)$. Patients with antibody titers $>1: 4,000$ also exhibited a statistically significant improvement in survival (11.7 months versus 3.6 months; $P=0.002) .{ }^{3}$ Toxicity from the vaccine was minimal in this trial, including mild flu-like symptoms and injection site reactions. ${ }^{48}$

A Phase III trial was done to evaluate overall survival with the use of CIMAVax in stage IIIb or IV NSCLC patients. Participants in the experimental group received CIMAVax and best supportive care after having received first-line chemotherapy. Participants in the control group received best supportive care and a placebo after first-line chemotherapy. Participants were divided into two subgroups: those younger than 60 and those older than 60. This Phase III trial is now complete and preliminary results show a significant increase in survival among the treatment group compared to the control group; final results are eagerly expected. ${ }^{49}$

\section{Conclusion}

Patients with NSCLC face a dismal prognosis at the time of diagnosis due to an advanced and aggressive disease, coupled with the limited available treatment options. Early studies of active immunotherapy have exhibited promising results for use with NSCLC, especially in advanced disease where the overall survival rate has, historically, been very grim. While therapeutic vaccination may not be a panacea, it could serve as a vital adjunct to traditional surgical and chemotherapeutic treatment regimens as we see in the case of the MAGE 3 vaccine for adjuvant therapy or in the case of CIMAVax where it is used with chemotherapy in advanced disease patients.

The identification of better antigenic targets, addition of immune-stimulating adjuvants, and production of improved delivery mechanisms has resulted in a group of vaccines that appear able to elicit an effective immune response against tumor cells. This has been a major change in the area of cancer immunology where lung cancer vaccines have never been a popular topic. Phase II studies show that these vaccines can produce statistically significant improvements in the PFS or overall survival for patients, irrespective of the stage of the patient's disease. These vaccines have demonstrated low toxicity together with improved survival and an enhanced quality of life relative to the baseline prognosis. As a result of these studies, for first time in the history of lung cancer and immunotherapy, several Phase III trials are ongoing to examine the efficacy of therapeutic vaccination in a larger number of patients with all stages of NSCLC. Further encouraging results from these studies could very well result in the clinical approval of therapeutic vaccines to combat NSCLC.

\section{Disclosure}

The authors report no conflicts of interest in this work.

\section{References}

1. Jemal A, Bray F, Center MM, Ferlay J, Ward E, Forman D. Global cancer statistics. CA Cancer J Clin. 2011;61(2):69-90.

2. Molina JR, Yang P, Cassivi SD, Schild SE, Adjei AA. Non-small cell lung cancer: epidemiology, risk factors, treatment, and survivorship. Mayo Clin Proc. 2008;83(5):584-594.

3. Cancer, N.C.I.N.T.N.-S.C.L. and Treatment, http://www.cancergov/cancertopics/pdq/treatment/non-small-celllung/healthprofessional/page2. 2011., $\left(\mathrm{PDQ}^{\circledR}\right)$. Available from http://www.cancer.gov/cancertopics/pdq/ treatment/non-small-cell-lung/healthprofessional/page2. Accessed May 30, 2013.

4. Rosell R, Skrzypski M, Jassem E, et al. BRCA1: a novel prognostic factor in resected non-small-cell lung cancer. PLoS One. 2007;2(11):e1129.

5. Belalcazar A, Raez LE, Santos ES. Immunotherapy for nonsmall-cell lung cancer. MEMO. 2012;5(2):90-93.

6. Kantoff PW, Higano CS, Shore ND, et al; IMPACT Study Investigators. Sipuleucel-T immunotherapy for castration-resistant prostate cancer. N Engl J Med. 2010;363(5):411-422.

7. Perez CA, Santos ES, Raez LE. Active immunotherapy for non-smallcell lung cancer: moving toward a reality. Expert Rev Anticancer Ther. 2011;11(10):1599-1605.

8. Nauts HC. Bacteria and cancer-antagonisms and benefits. Cancer Surv. 1989;8(4):713-723. 
9. Jaffee EM, Pardoll DM. Murine tumor antigens: is it worth the search? Curr Opin Immunol. 1996;8(5):622-627.

10. Papac DI, Briggs JB, Chin ET, Jones AJ. A high-throughput microscale method to release N-linked oligosaccharides from glycoproteins for matrix-assisted laser desorption/ionization time-of-flight mass spectrometric analysis. Glycobiology. 1998;8(5):445-454.

11. Brichard VG, Lejeune D. Cancer immunotherapy targeting tumourspecific antigens: towards a new therapy for minimal residual disease. Expert Opin Biol Ther. 2008;8(7):951-968.

12. Robert C, Thomas L, Bondarenko I, et al. Ipilimumab plus dacarbazine for previously untreated metastatic melanoma. $N$ Engl $J$ Med. 2011;364(26):2517-2526.

13. Kelly RJ, Giaccone G. Lung cancer vaccines. Cancer J. 2011;17(5): 302-308.

14. De Pas T, Giovannini M, Rescigno M, et al. Vaccines in non-small cell lung cancer: rationale, combination strategies and update on clinical trials. Crit Rev Oncol Hematol. 2012;83(3):432-443.

15. Reck M. What future opportunities may immuno-oncology provide for improving the treatment of patients with lung cancer? Ann Oncol. 2012;23 Suppl 8:viii28-viii34.

16. Decoster L, Wauters I, Vansteenkiste JF. Vaccination therapy for nonsmall-cell lung cancer: review of agents in phase III development. Ann Oncol. 2012;23(6):1387-1393.

17. Thomas A, Hassan R. Immunotherapies for non-small-cell lung cancer and mesothelioma. Lancet Oncol. 2012;13(7):e301-e310.

18. Issell BF, Valdivieso M, Hersh EM, Richman S, Gutterman JU, Bodey GP. Combination chemoimmunotherapy for extensive non-oat cell lung cancer. Cancer Treat Rep. 1978;62(7):1059-1063.

19. Yasumoto K, Manabe H, Yanagawa E, et al. Nonspecific adjuvant immunotherapy of lung cancer with cell wall skeleton of Mycobacterium bovis Bacillus Calmette-Guérin. Cancer Res. 1979;39(8):3262-3267.

20. Yamamura Y, Sakatani M, Ogura T, Azuma I. Adjuvant immunotherapy of lung cancer with BCG cell wall skeleton (BCG-CWS). Cancer. 1979;43(4):1314-1319.

21. Hadźiev S, Mandulova P, Kavaklieva-Dimitrova J, Penev K, Spassova M, Madźarova S. BCG immunotherapy of lung cancer in a district oncology dispensary. I. Study of 860 patients with histologic diagnosis. Neoplasma. 1982;29(1):93-110.

22. Maurer LH, Pajak T, Eaton W, et al. Combined modality therapy with radiotherapy, chemotherapy, and immunotherapy in limited small-cell carcinoma of the lung: a Phase III cancer and Leukemia Group B Study. J Clin Oncol. 1985;3(7):969-976.

23. Matthay RA, Mahler DA, Beck GJ, et al. Intratumoral Bacillus CalmetteGuérin immunotherapy prior to surgery for carcinoma of the lung: results of a prospective randomized trial. Cancer Res. 1986;46(11):5963-5968.

24. Giaccone G, Debruyne C, Felip E, et al. Phase III study of adjuvant vaccination with $\mathrm{Bec} 2 /$ bacille Calmette-Guerin in responding patients with limited-disease small-cell lung cancer (European Organisation for Research and Treatment of Cancer 08971-08971B; Silva Study). J Clin Oncol. 2005;23(28):6854-6864.

25. Lipson SD, Chretien PB, Makuch R, Kenady DE, Cohen MH. Thymosin immunotherapy in patients with small cell carcinoma of the lung: correlation of in vitro studies with clinical course. Cancer. 1979;43(3): 863-870.

26. Schiller JH, Morgan-Ihrig C, Levitt ML. Concomitant administration of interleukin-2 plus tumor necrosis factor in advanced non-small cell lung cancer. Am J Clin Oncol. 1995;18(1):47-51.

27. Jansen RL, Slingerland R, Goey SH, Franks CR, Bolhuis RL, Stoter G. Interleukin-2 and interferon-alpha in the treatment of patients with advanced non-small-cell lung cancer. J Immunother. 1992;12(1): 70-73.

28. Lissoni P, Tisi E, Barni S, et al. Biological and clinical results of a neuroimmunotherapy with interleukin-2 and the pineal hormone melatonin as a first line treatment in advanced non-small cell lung cancer. $\mathrm{Br} J$ Cancer. 1992;66(1):155-158.

29. Lara PN, Laptalo L, Longmate J, et al; California Cancer Consortium. Trastuzumab plus docetaxel in HER2/neu-positive non-small-cell lung cancer: a California Cancer Consortium screening and phase II trial. Clin Lung Cancer. 2004;5(4):231-236.
30. Vuillez JP, Kraeber-Bodéré F, Moro D, et al. Radioimmunotherapy of small cell lung carcinoma with the two-step method using a bispecific anti-carcinoembryonic antigen/anti-diethylenetriaminepentaacetic acid (DTPA) antibody and iodine-131 Di-DTPA hapten: results of a phase I/II trial. Clin Cancer Res. 1999;5(Suppl 10):3259s-3267s.

31. Kong F, Jirtle RL, Huang DH, Clough RW, Anscher MS. Plasma transforming growth factor-beta1 level before radiotherapy correlates with long term outcome of patients with lung carcinoma. Cancer. 1999;86(9):1712-1719.

32. Nemunaitis J, Dillman RO, Schwarzenberger PO, et al. Phase II study of belagenpumatucel- $\mathrm{L}$, a transforming growth factor beta- 2 antisense gene-modified allogeneic tumor cell vaccine in non-small-cell lung cancer. J Clin Oncol. 2006;24(29):4721-4730.

33. NovaRx Corporation. Phase III Lucanix vaccine therapy in advanced nonsmall-cell lung cancer (NSCLC) following front-line chemotherapy (STOP). Available from: http://www.clinicaltrials.gov/ct2/show/NCT00676507. NLM identifier: NCT00676507. Accessed February 1,2012.

34. Sienel W, Varwerk C, Linder A, et al. Melanoma associated antigen (MAGE)-A3 expression in Stages I and II non-small cell lung cancer: results of a multi-center study. Eur J Cardiothorac Surg. 2004;25(1): 131-134.

35. Vansteenkiste J, Zielinski M, Linder A, et al. Final results of a multicenter, double-blind, randomized, placebo-controlled phase II study to assess the efficacy of MAGE-A3 immunotherapeutic as adjuvant therapy in stage IB/II nonsmall cell lung cancer (NSCLC). J Clin Oncol. 2006;s25:7554.

36. GlaxoSmithKline. GSK1572932A antigen-specific cancer immunotherapeutic as adjuvant therapy in patients with non-small-cell lung cancer. Available from: http://www.clinicaltrials.gov/ct2/show/ NCT00480025. NLM identifier: NCT00480025. Accessed February 1, 2012.

37. Raina D, Kosugi M, Ahmad R, et al. Dependence on the MUC1-C oncoprotein in non-small cell lung cancer cells. Mol Cancer Ther. 2011;10(5):806-816.

38. Butts C, Murray N, Maksymiuk A, et al. Randomized phase IIB trial of BLP25 liposome vaccine in stage IIIB and IV non-small-cell lung cancer. J Clin Oncol. 2005;23(27):6674-6681.

39. Butts C, Maksymiuk A, Goss G, et al. A multi-centre phase IIB randomized controlled study of BLP25 liposome vaccine (L-BLP25 or Stimuvax) for active specific immunotherapy of non-small cell lung cancer (NSCLC): updated survival analysis: B1-01. J Thor Oncol. 2007;2(8):s332-s333.

40. EMD Serono. Cancer vaccine study for unresectable stage III non-small cell lung cancer. Available from: http:/ www.clinicaltrials.gov/ct2/show/ NCT00409188. NLM identifier: NCT00409188. Accessed February 1, 2012.

41. Rochlitz C, Figlin R, Squiban P, et al. Phase I immunotherapy with a modified vaccinia virus (MVA) expressing human MUC1 as antigenspecific immunotherapy in patients with MUC1-positive advanced cancer. J Gene Med. 2003;5(8):690-699.

42. Ramlau R, Quoix E, Rolski J, et al. A phase II study of Tg4010 (Mva-Muc1-I12) in association with chemotherapy in patients with stage III/IV Non-small cell lung cancer. $J$ Thorac Oncol. 2008;3(7): 735-744.

43. Acres B, Quoix E, Ramlau R, et al. Therapeutic vaccination with TG4010 and first-line chemotherapy in advanced non-small-cell lung cancer: a controlled phase 2B trial. Lancet Oncol. 2011;12(12): $1125-1133$.

44. Clinicaltrials.gov: Immunotherapy with TG4010 in patients with advanced non-small-cell lung cancer http://clinicaltrials.gov/ct2/show/ NCT01383148. Accessed February 1, 2012.

45. Rodriguez G, Airama A, Viña L, et al. Manufacturing process development for an epidermal growth factor-based cancer vaccine. Int Biopharm. 2008;21(10):36-42.

46. González G, Crombet T, Catalá M, et al. A novel cancer vaccine composed of human-recombinant epidermal growth factor linked to a carrier protein: report of a pilot clinical trial. Ann Oncol. 1998;9(4): $431-435$. 
47. González G, Crombet T, Neninger E, Viada C, Lage A. Therapeutic vaccination with epidermal growth factor (EGF) in advanced lung cancer: analysis of pooled data from three clinical trials. Hum Vaccin. 2007;3(1):8-13.

48. Neninger Vinageras E, de la Torre A, Osorio Rodríguez M, et al. Phase II randomized controlled trial of an epidermal growth factor vaccine in advanced non-small-cell lung cancer. J Clin Oncol. 2008;26(9):1452-1458.
49. Bioven Sdn. Bhd. Vaccine therapy in treating patients with non-small cell lung cancer (NSCLC) stages IIB/IV. Available from: http:// www.clinicaltrials.gov/ct2/show/NCT00516685. NLM identifier: NCT00516685. Accessed July 11, 2012.

\section{Publish your work in this journal}

ImmunoTargets and Therapy is an international, peer-reviewed open access journal focusing on the immunological basis of diseases, potential targets for immune based therapy and treatment protocols employed to improve patient management. Basic immunology and physiology of the immune system in health, and disease will be also covered. In addition, the journal will focus on the impact of manage-
Dovepress

ment programs and new therapeutic agents and protocols on patient perspectives such as quality of life, adherence and satisfaction. The manuscript management system is completely online and includes a very quick and fair peer-review system, which is all easy to use. Visit http://www.dovepress.com/testimonials.php to read real quotes from published authors.

Submit your manuscript here: http://www.dovepress.com/immunotargets-and-therapy-journal 